CORRELATION BETWEEN PERIODONTAL INDICES [PLAQUE INDEX (PI), GINGIVAL INDEX (GI)] AND GLYCATED HEMOGLOBIN (HBA 1C), IN TYPE 2 DIABETES MELLITUS.
KEY WORDS: 1. Periodontal indices, 2. Plaque index, 3 . gingival index, 4. Glycated hemoglobin (HbAlc),

\section{Dr Gargi}

Sharma*

Dr Priyanka

Singh

\section{Dr Guljot singh}

Tutor/Demonstrator,Dental Dept.Jhalawar Medical College,Jhalawar,Rajasthan. *Corresponding Author

\section{$3^{\text {rd }}$ year MDS student, Saraswati Dental College, Lucknow, UP .}

Objectives: The objective was to find out Correlation between the clinical (periodontal indices) and metabolic changes (glycated hemoglobin) following non-surgical periodontal treatment (pre and post), in diabetic (Type 2) patients.

Material and methods: Forty type 2 diabetic patients with generalized chronic periodontitis were selected. Subjects were randomly assigned into two groups.

Data collection: Periodontal indices [Plaque index (PI), gingival index (GI)], were recorded at baseline, $1^{\text {st }}$ and $3^{\text {rt }}$ months. glycated hemoglobin (HbAlc), was analyzed at baseline, $1^{\text {st }}$ and $3^{\text {rd }}$ months following the non surgical periodontal therapy. The treatment group received scaling and root planning whereas the control group received no periodontal treatment.

Results: The results showed significant Correlation between periodontal indices and, levels of $\mathrm{HbA}_{1 \mathrm{c}}$ in Type 2 diabetes mellitus patients.

Summary and conclusions: Non surgical periodontal therapy is associated with improved glycemic control in Type 2 diabetes mellitus patients.

\section{INTRODUCTION}

Diabetes Mellitus, the most widespread disease of mankind, is a syndrome characterized by chronic hyperglycemia and disturbance of carbohydrate, fat and protein metabolism associated with absolute or relative deficiencies in insulin secretion and/or insulin action ${ }^{1}$.

Prevalence of diabetes in adults worldwide was estimated to be $4.0 \%$ in 1995 and predicted to rise to $5.4 \%$ in the year $2025^{2}$. It is higher in developed than in developing countries. The number of adults with diabetes in the world will rise from 135 million in 1995 to 300 million in the year $2025^{2}$. There will be $42 \%$ increase, from 51 to 72 million, in the developed countries and a $170 \%$ increase from 84 to 228 million, in the developing countries ${ }^{3}$. Periodontal disease is an infection that affects the periodontium, the tissues that support the teeth. It is bacterial infection caused by gram negative anaerobes, which populate the sub gingival plaque. These putative pathogens Include Aggregatibacter actinomycetecomitans, Porhyromonas ginvivalis, Prevotella intermedia, Bacteroides forsythus and Spirochetes. Gram negative organisms specifically of the Bacteriodes species may affect the endocrine metabolic status of the diabetic patient.

Research has been conducted into the relationship between diabetes and periodontal disease since the $1960 \mathrm{~s} .{ }^{5}$ Prevalence of periodontal disease among individuals with inadequately controlled type-2 diabetes mellitus is generally higher than that of people free of systemic disorder. ${ }^{4}$ Scientific evidence on the effects of periodontal disease and diabetes has emerged lately.Various studies have correlated response to periodontal treatment in diabetic patients and its influence on their metabolic control ${ }^{5}$.

\section{AIM \& OBJECTIVES}

The objective was to find out Correlation between the clinical (periodontal indices) and metabolic changes (glycated hemoglobin) following non-surgical periodontal treatment (pre and post), in diabetic (Type 2) patients.

\section{METHODOLOGY}

A prospective, interventional, comparative, clinical study was carried out on 40 type 2 diabetic patients with generalized chronic periodontitis. The patients were selected for study

according to inclusion and exclusion criteria (table 1). Patients were in follow up for 3 months.

\title{
Table 1: Inclusion and Exclusion Criteria
} \section{INCLUSION CRITERIA}

1. Age group: 35-70 years

2. Presence of moderately controlled type 2 diabetes mellitus with $\mathrm{HbAlc} 6-8 \%$

3. Clinical diagnosis of generalized chronic periodontitis with probing Pocket depth.

4. No major diabetic complications like retinopathy, nephropathy, cardiopathy and cerebrovascular changes. 4

5. No periodontal treatmen six months prior to the study

\section{Study consisted of 2 groups:}

After randomization by computer software Group I - (Study group) consisted of 20 patients with type II Diabetes Mellitus who were subjected for scaling and root planning. Group II (Control group) - consisted of 20 patients with type II Diabetes Mellitus who were not be subjected for scaling and root planning. Procedure: All subjects were asked to report to the clinic after fasting over night (8-12 hours) and the recordings of the dental status were made. The following dental variables were measured; Plaque index (Sillness and Loe), Gingival bleeding index (Loe and Sillness).

\section{Treatment Regimen}

Conventional periodontal treatment, scaling and root planning under local anesthesia (if necessary) will be carried out.

After scaling and root planning, following periodontal parameters were recorded at baseline:

Plaque Index (PI), Loe H., (1967) ${ }^{6}$ A mouth mirror and a dental probe were used after air drying of the teeth to assess 
plaque on four gingival areas of the tooth that is- distal -facial, mesial- facial, facial and ligual surfaces of each tooth. Assessed according to the Criteria (Table 2,3)

\section{Table 2: Plaque Index (PI) Criteria}

0 No plaque

1 A film of plaque adhering to the free Gingival margin and adjacent area of the tooth.

2 The plaque may be recognized only by running a probe across the tooth surface.

3 Moderate accumulation of soft deposits with in the gingival pocket, on the gingival margin and / or adjacent tooth surface, which can be seen with the naked eye.

4 Abundance of soft matter with in the gingival pocket and/ or on the tooth and gingival margin.

Total score

Plaque score/person =

Number of surfaces examined

Table 3: Plaque Index (PI) Score

\begin{tabular}{|c|c|}
\hline Score & Conditions \\
\hline 0 & Excellent \\
\hline $0.1-0.9$ & Good \\
\hline $1.0-1.9$ & Fair \\
\hline $2.0-3.0$ & Poor \\
\hline
\end{tabular}

Gingival Index (GI), Loe and Silness, $(1963)^{6}$ The tissue surrounding each tooth is divided into four gingival scoring units: distal facial papilla, facial margin, mesial facial papilla and the entire lingual gingival margin. Periodontal probe and mouth mirror was used to assess the gingival tissue. Each of the four gingival units is assessed according to the criteria (Table 4,5):

\section{Table 4: Gingival Index (GI) criteria}

\section{Normal Gingiva}

1 Mild inflammation, slight changes in color, slight edema no bleeding on probing.

2 Moderate inflammation, redness, edema and glazing, bleeding on probing.

3 Severe inflammation marked redness and edema, ulcerations, tendency to spontaneous bleeding.

Total score

Gingival score/ person

$$
\text { Number of surfaces examined }
$$

Table 5: Gingival Index (GI) Scores

\begin{tabular}{|c|c|}
\hline Gingival Scores & Condition \\
\hline $0.1-1.0$ & Mild gingivitis \\
\hline $1.1-2,0$ & Moderate gingivitis \\
\hline $2.1-3.0$ & Severe gingivitis \\
\hline
\end{tabular}

Glycated Hemoglobin (HbAlc test) ${ }^{7}$ Glycosylated (or glycated) hemoglobin (Hemoglobin Alc, HbAlc,) In the normal 120-day life span of the red blood cell, glucose molecules react with hemoglobin, forming glycated hemoglobin used primarily to identify the average plasma glucose concentration over prolonged periods of time. It is formed in, none enzymatic pathway by hemoglobin's normal exposure to high plasma levels of glucose. According to American Diabetic Association (ADA) 20107: Below 6.5\%, Non diabetic and Above or equal 6.5\% Diabetic (Table 6).

\section{Table 6: Criteria for the Diagnosis of Diabetes}

\begin{tabular}{|l|l|l|}
\hline \multicolumn{2}{|l|}{ Criteria for the Diagnosis of Diabetes } \\
\hline $\begin{array}{l}\text { Measureme } \\
\text { ntes }\end{array}$ & $\begin{array}{l}\text { Diagnostic } \\
\text { Values for } \\
\text { Diabetes }\end{array}$ & Characteristics \\
\hline
\end{tabular}

\begin{tabular}{|l|l|l|}
\hline $\begin{array}{l}\text { Glycosylated } \\
\text { hemoglobin } \\
\text { (HbAlc) }\end{array}$ & $\geq 6.5 \%$ & $\begin{array}{l}\text { The test should be performed in } \\
\text { a laboratory using the } \\
\text { standarized method. It reflects } \\
\text { average blood glucose levels } \\
\text { over a 2- to 3-month period of } \\
\text { time }\end{array}$ \\
\hline
\end{tabular}

Criteria for the Diagnosis of Diabetes mellitus (ADA2010) ${ }^{7}$

\section{Recall / follow up and Statistical Analysis}

The periodontal parameters were recorded again at, 3 month interval. Patient were re-evaluated for clinical parameters like Plaque Index, Gingival Index and Biochemical investigation namely Glycated hemoglobin. The results are given as mean and standard deviation values. To compare the two groups, $t$ paired and t unpaired test was used.

\section{RESULTS}

Total of forty subjects belonging to an age group of 35-70 years were included in the study. Subjects included were 20 men and 20 women and Mean age were Study group 50.46 years and Control group 40.73 years. (Table 7 , Graph 1)

\section{Periodontal indices}

Plaque index: The mean plaque score at baseline was 1.7985 in the study group and 1.8185 in the control group. At the baseline the mean plaque index score was not statistically significant between the groups ( $p=0.645 \mathrm{~ns}$ ). It was observed that the mean plaque index score was statistically significant at the 3rd month when compared between the groups $(p=0.001$ VHS) (Table 8 Graph I) Gingival index scores: The gingival index score, Intergroup comparisons showed statistically significant difference at the $3^{\text {rd }}$ month $(p=0.002$ vhs) (Table 8). The mean gingival index score in the study group was 1.6930 and 1.6910 in the control group. There was no statistically significant difference in the gingival index score between the study and the control group at baseline ( $\mathrm{p}=0.935 \mathrm{~ns})$ (Table $8 \mathrm{Graph} \mathrm{I})$.

\section{Metabolic parameter}

Glycated Hemoglobin (HbAlc): The baseline mean $\mathrm{HbAlc}$ value for the study group was $6.9450 \pm .96599$ and for the control group was $6.7750 \pm .75803$. At baselines were no statistically significant differences between the two groups. Both the groups showed moderate metabolic control. At $3^{\text {rd }}$ month mean $\mathrm{HbAlc}$ value for the study group was 6.6944 \pm 0.84260 and for the control group was $7.5500 \pm 0.58264$. At $3^{\text {rd }}$ month were statistically highly significant differences between the two groups. Study groups showed better metabolic control. (Table 8 Graph I).

\section{CONCLUSION}

Conclusion can be derived from the present study that periodontal care should be undertaken along with standard measures for the diabetic. In Type 2 diabetes mellitus patients periodontal indices and glycated hemoglobin strongly correlated and Non surgical periodontal therapy is associated with improved glycemic control of patients.

Table 7: Demographics of study

\begin{tabular}{|l|l|l|l|l|}
\hline $\begin{array}{l}\text { Group (T2DIM and } \\
\text { CGP) }\end{array}$ & Mean age & male & female & Total no \\
\hline Study group & 50.46 & 8 & 12 & 20 \\
\hline Control group & 40.73 & 12 & 8 & 20 \\
\hline $\begin{array}{l}\text { T2DM = type 2 diabetes mellitus } \\
\text { CGP = chronic generalized periodontitis }\end{array}$ \\
\hline
\end{tabular}

Table 8: Comparison of plaque index, gingival index and Hbalc between study and control group at baseline and $3^{\text {rd }}$ month

\begin{tabular}{|c|c|c|c|c|c|c|}
\hline \multicolumn{2}{|c|}{ Parameters } & N & MEAN & $\begin{array}{c}\text { Std. } \\
\text { deviation }\end{array}$ & P \\
\hline $\begin{array}{c}\text { Plaque } \\
\text { index }\end{array}$ & Baseline & $\begin{array}{c}\text { Study } \\
\text { Control }\end{array}$ & 20 & 1.7985 & 0.53386 & $\begin{array}{c}\mathrm{P}=0.645 \\
20\end{array}$ \\
\hline
\end{tabular}




\begin{tabular}{|c|c|c|c|c|c|c|}
\hline & 3 months & \begin{tabular}{|c|} 
Study \\
Control
\end{tabular} & $\begin{array}{l}20 \\
20\end{array}$ & $\begin{array}{l}1.6217 \\
1.8635\end{array}$ & $\begin{array}{l}0.19355 \\
0.22399\end{array}$ & $\begin{array}{c}\mathrm{P}=0.001 \\
\text { vhs. }\end{array}$ \\
\hline \multirow{3}{*}{$\begin{array}{c}\text { Gingiv } \\
\text { al } \\
\text { index }\end{array}$} & Baseline & & 20 & 1.6930 & 0.28075 & $\mathrm{p}=0.93$ \\
\hline & & Control & 20 & 1.6910 & 0.26392 & $5 \mathrm{~ns}$ \\
\hline & 3 months & \begin{tabular}{|c|} 
Study \\
Control
\end{tabular} & $\begin{array}{l}20 \\
20\end{array}$ & $\begin{array}{l}1.5861 \\
1.8505\end{array}$ & $\begin{array}{l}0.15549 \\
0.32034\end{array}$ & $\begin{array}{c}\mathrm{P}=0.002 \\
\text { hs }\end{array}$ \\
\hline \multirow[t]{2}{*}{ Hbalc } & Baseline & \begin{tabular}{|c|} 
Study \\
Control
\end{tabular} & $\begin{array}{l}20 \\
20\end{array}$ & $\begin{array}{l}6.9450 \\
6.7750\end{array}$ & $\begin{array}{l}0.96599 \\
0.75803\end{array}$ & $0.575 \mathrm{~ns}$ \\
\hline & 3 months & \begin{tabular}{|c|} 
Study \\
Control
\end{tabular} & $\begin{array}{l}20 \\
20\end{array}$ & $\begin{array}{l}6.6944 \\
7.5500\end{array}$ & $\begin{array}{l}0.84260 \\
0.58264\end{array}$ & $\begin{array}{c}0.002 \\
\text { vhs }\end{array}$ \\
\hline
\end{tabular}

NS = Not significant, $\mathrm{HS}=$ high significant, VHS =Very high significant

\section{Graph 1}

\section{Demography of study}

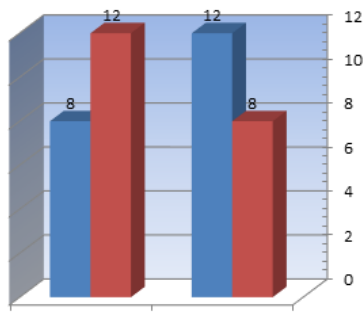

Study group
Male
controle group
Wemale

Plaque Index

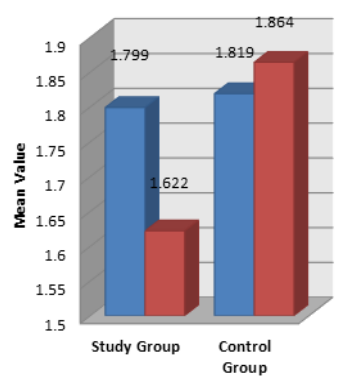

Base $\square 3$ Months

\section{Glycated HB(HbA1c)}

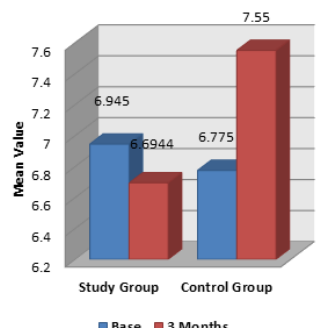

Gingival Index

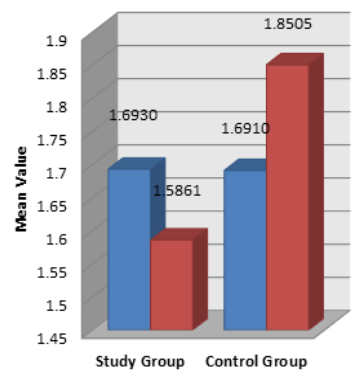

Base 13 Months

\section{REFERENCES}

1. Kahr CR, Weire GC, Lea \& Febiger. Joslin's diabetes mellitus, $13^{\text {th }}$ ed. Philadelphia, 1994; 193-194.

2. WHO Diabetes Mellitus. Report of a WHO study group. Technical report series No.727,WHO Geneva 1985.

3. King H, Aubert RE, Herman WH. Global burden of diabetes. Prevalence numerical estimates and projections. Diabetes care 1998;21:1414-31.

4. Stewart JE,Wager KA. The effect of periodontal treatment on glycemic control in patients with type 2 diabetes mellitus. Journal of Clinical Periodontology 2001;28:306-310

5. Ricardo Faria, Navarro Ana. Clinical and metabolic changes after Conventional treatment of type 2 diabetes patients with chronic periodontitis. Journal of Periodontology 2006; 77:591-598.

6. Loe $\mathrm{H}$ : The gingival index, the Plaque index and the retention index systems. Journal of Periodontal 1967;38:610.

7. American Diabetes Association. Diagnosis and classification of diabetes mellitus.Diabetes Care 2010; 33(Suppl.1):S62-S69 